\title{
PENERAPAN SANKSI PIDANA TERHADAP PELAKU PERDAGANGAN MANUSIA (HUMAN TRAFFICKING) DI INDONESIA
}

\author{
Brian Septiadi Daud ${ }^{1 *}$, Eko Sopoyono ${ }^{2}$ \\ ${ }^{1}$ Fakultas Hukum, Universitas Ichsan Gorontalo \\ ${ }^{2}$ Fakultas Hukum, Universitas Diponegoro \\ septiadybrian@gmail.com
}

\begin{abstract}
Human trafficking is a fairly widespread crime practice in Indonesia, which threatens life in society. The problem discussed is how the legal arrangements regarding human trafficking in force in Indonesia, in this case the Law on human commerce and the Criminal Code. And how the application of criminal sanctions against human traffickers in Indonesia. The purpose of this study is to determine the causes of human trafficking in the applicable regulations and the application of sanctions in the legal system. This research method uses a normative juridical approach which looks at the problem from the study of legal materials such as books or articles that discuss human trafficking as a reference for staples and secondary legal materials. The results of this study are human trafficking which is rife in various countries, including Indonesia and developing countries where this is a concern of the world, especially UN. Human trafficking is categorized as a criminal act, which is more specifically a specific criminal act. In Indonesian criminal law has been regulated by various provisions. Provisions include prohibitions and eradication as stated in the Criminal Code, Legislation and in the Criminal Code Bill, Chapter XX, Articles 546-561 concerning human trafficking, where the application of sanctions is threatened with imprisonment and fines. Human trafficking is an organized and systematic crime, in which the people included have personal or group interests for profit.

Keywords: Human Trafficking; Legal Regulations; Application of Criminal Sanctions.
\end{abstract}

\begin{abstract}
ABSTRAK
Perdagangan manusia merupakan praktik kejahatan yang terbilang marak di Indonesia, dimana mengancam kehidupan dalam masyarakat. Permasalahan yang dibahas adalah Bagaimana pengaturan hukum tentang perdagangan manusia yang berlaku di Indonesia, dalam hal ini Undang-Undang tentang perdaganagan manusia dan KUHP. Dan Bagaimana penerapan sanksi pidana terhadap pelaku perdagangan manusia di indonesia. Tujuan penelitian ini untuk mengetahui penyebab terjadinya perdagangan manusia secara peraturan yang berlaku dan penerapan sanksi dalam sistem hukum. Metode Penelitian ini menggunakan pendekatan yuridis normatif dimana melihat permasalahan dari kajian bahan-bahan hukum seperti buku atau artikel yang membahas tentang perdagangan manusia sebagai referensi bahan pokok dan bahan hukum sekunder. Hasil dari penelitian ini adalah Perdagangan manusia yang marak diberbagai negara, termasuk Indonesia dan negara-negara berkembang dimana hal ini menjadi perhatian dunia terutama PBB. Perdagangan manusia dikategorikan sebagai tindak pidana, yang lebih tepatnya tindak pidana khusus. Dalam hukum pidana Indonesia telah diatur dengan berbagai ketentuan. Ketentuan mencakup larangan dan pemberantasan seperti disebutkan didalam KUHP, Peraturan Perundang-Undangan dan didalam RUU KUHP, Bab XX, Pasal 546-561 tentang perdagangan manusia, yang penerapan sanksinya diancam dengan hukum pidana pidana penjara dan hukum pidana denda. Perdagangan manusia merupakan kejahatan yang terorganisir dan tersistematis, dimana orang yang termasuk didalamnya memiliki kepentingan pribadi atau kelompok untuk mendapat keuntungan.
\end{abstract}

Kata Kunci : Perdagangan Manusia; Pengaturan Hukum; Penerapan Sanksi Pidana.

\footnotetext{
${ }^{*}$ Corresponding Author
} 


\section{A. PENDAHULUAN}

Pandangan publik tentang perdagangan orang terkait dengan sikap kesadaran hukum tentang pentingnya aturan dalam bentuk hukum positif. Terkait dengan tingkat kesadaran hukum yang dipahami melalui pemahaman tentang diberlakukannya undang-undang, tetapi lebih pada tingkat implementasi, sehingga pemahaman perdagangan tidak hanya pada tingkat konsep, tetapi juga lebih pada tingkat implementasi , atau aplikasi yang berkaitan dengan kesadaran hukum.

Perdagangan orang telah berlangsung lama yang bertentangan dengan martabat dan martabat manusia. Ini adalah pelanggaran hak asasi manusia, yang seharusnya manusia dilindungi di bawah Pancasila dan UUD 1945. Perdagangan orang adalah kejahatan yang terorganisasi dengan baik, dari metode konvensional hingga modern. Dalam kejahatan terorganisir ini, membangun jaringan dari Nasional ke Internasional (Prakoso, \& Nurmalinda, 2018). Kejahatan terorganisi ini mencakup setiap kelompok orang yang beraktivitas utamanya adalah melanggar hukum pidana untuk mendapatkan keuntungan illegal dan kekuasaaan dengan melakukan aktivitas kejahatan (Rosnawati, Din \& Mujibussalim, 2016).

Secara historis, perdagangan orang dapat dikatakan sebagai perbudakan dan juga melanggar hak asasi manusia. Kondisi ini berkembang dalam komunitas ekonomi yang memiliki tingkat ekonomi yang lemah, kurangnya pemahaman agama atau moralitas, dan bergantung pada kelompok komunitas ekonomi yang kuat (Satriani, \& Muis, 2013). Alasan yang diberikan oleh korban pada umumnya adalah tindakan legal berdasarkan perjanjian. Pelanggaran HAM dalam bentuk perbudakan pada umumnya dalam bentuk perampasan kebebasan dari seseorang, yang dilakukan oleh kelompok ekonomi yang kuat ke kelompok ekonomi yang lemah. Oleh karena itu, atas dasar itu pencegahan perdagangan orang dari perspektif pelanggaran hak asasi manusia harus dilakukan secara komprehensif dan integral, yang dapat dilakukan melalui tingkat kebijakan hukum pidana melalui legislasi, pelaksanaan, dan peradilan (Munthe, 2015).

Pemerintah Indonesia telah mengesahkan Undang-undang Nomor 21 Tahun 2007 tentang Pemberantasan Tindak Pidana Perdagangan Orang dengan pertimbangan bahwa setiap orang sebagai makhluk Tuhan Yang Maha Esa memiliki hak-hak asasi sesuai dengan kemuliaan harkat dan martabatnya serta dilindungi secara hukum oleh Undang-Undang Dasar RI 1945 sebagaimana dicantumkan dalam Pasal 28A bahwa: " Setiap orang berhak untuk hidup serta berhak mempertahankan hidup dan kehidupannya" (Azizurrahman, 2014).

Penegakan hukum tentang kejahatan perdagangan manusia di Indonesia masih belum optimal di mana kita dapat melihat ini dari berita di media baik di media cetak maupun elektronik sehingga banyak kasus perdagangan manusia diidentifikasi sebagai korban perdagangan manusia tetapi untuk menjerat pelaku perdagangan manusia sangat sulit karena dari modus operandi ternyata 
pelakunya lebih dari satu orang dan perusahaan, dan jika para pelaku ditemukan maka semakin sulit untuk melanjutkan ke pengadilan untuk mendapatkan sanksi pidana karena untuk bukti itu harus dipandu oleh prosedur pidana hukum, yaitu Hukum Acara Pidana yang memiliki prinsip bahwa hakim tidak diperbolehkan untuk melakukan kejahatan terhadap seseorang kecuali ada setidaknya dua bukti yang sah, ia memiliki keyakinan bahwa suatu tindak pidana benar-benar terjadi dan bahwa terdakwa bersalah untuk melakukan hal itu, sebagaimana diatur dalam Pasal 183 KUHAP.

Praktek perdagangan orang telah menjadi kejahatan yang mengancam kehidupan masyarakat umum, terutama orang-orang yang rentan, berpenghasilan rendah dan berpendidikan rendah. Dalam Buku Putih Pertahanan RI 2015, dinyatakan bahwa salah satu ancaman nyata adalah pelanggaran wilayah perbatasan. Beberapa pelanggaran di wilayah perbatasan termasuk perdagangan manusia (narkoba, senjata, manusia), pembalakan liar, penangkapan ikan ilegal. Berdasarkan Peraturan Menteri Pertahanan No. 57 tahun 2014 tentang Pedoman Pertahanan Strategis Nirmilter, salah satu ancaman terhadap dimensi sosial-budaya adalah perdagangan manusia. Perdagangan manusia atau perdagangan orang adalah kejahatan yang melanggar hak asasi manusia dan mengancam keamanan dan keselamatan warga negara, terutama calon migran yang akan pergi ke luar negeri (Riadi, 2017).
Dalam menemukan pelaku kejahatan perdagangan manusia ini sangat sulit karena biasanya para korban telah direkrut terlebih dahulu oleh agen perekrutan ilegal dan agen ilegal ini membayar calo perorangan yang tidak memiliki izin untuk merekrut pekerja atau mengatur dokumen perjalanan terkait dengan pencari kerja. Kemudian para korban yang telah dijerat oleh perekrut, baik agen maupun perorangan, akhirnya ditawan dan dieksploitasi dengan berbagai cara bahkan hingga kekerasan fisik dan kekerasan seksual. Masalah penegakan hukum dalam perdagangan orang harus diberantas sepenuhnya mulai dari perekrutan, transportasi, tempat tinggal, transfer pemindahan atau penerimaan seseorang dengan ancaman kekerasan, penculikan penculikan, pemalsuan, penipuan dan penyalahgunaan kekuasaan, atau posisi rentan, jeratan hutang atau pembayaran untuk mendapatkan pembayaran harus mendapat persetujuan dari orang yang mengendalikan orang lain (Kamea, 2016).

Berdasarkan uraian diatas dapat ditarik pokok permasalahan yang akan dirumuskan dalam penelitian ini yaitu : Pertama, Bagaimana pengaturan hukum tentang perdagangan orang (human trafficking) yang berlaku di Indonesia ?, Kedua, Bagaimana penerapan sanksi pidana terhadap pelaku perdagangan orang (human trafficking) di indonesia?

Perdagangan orang merupakan perilaku yang menyimpang dari norma-norma yang ada dalam suatu sistem sosial. Paul Horton mengemukakan ada 
enam ciri-ciri perilaku menyimpang diantaranya: Penyimpangan harus dapat didefenisikan, Penyimpangan bisa juga diterima bisa juga ditolak, Penyimpangan relatif dan penyimpangan mutlak, Penyimpangan terhadap budaya nyata dan budaya ideal, Terdapat norma-norma penghindaran, Penyimpangan sosial yang bersifat adaptif (penyesuaian). Penyimpangan sosial bisa juga di kategorikan sebagai patologi sosial yang berarti penyakit masyarakat/sosial atau merupakan segenap tingkah laku manusia yang dianggap tidak sesuai, melanggar norma-norma umum dan adat istiadat, atau tidak terintegrasi dengan tingkah laku umum, diantaranya yaitu: perjudian, korupsi, kriminologi, pelacuran, penyalahan narkotika dan obat-obat terlarang, perkelahian antar pelajar atau mahasiswa, homoseks dan alkoholisme (Rahmawati, 2016).

Dalam teori assosiasi diferensial merupakan teori yang melihat suatu kejahatan dari perilaku penyimpang yang ada didalam masyarakat.

Dalam UU No. 21 Tahun 2007 Tentang Pemberantasan Tindak Pidana Perdagangan Orang yang saat ini diberlakukan tidak jauh berbeda dengan rumusan dari Protokol PBB dan lebih rinci atau mencakup ruang lingkup tindak pidana perdagangan orang dari rumusan KUHP. Dalam pasal 1 angka 1 menyatakan bahwa perdagangan orang adalah tindakan perekrutan, pengangkutan, penampungan, pengiriman, pemindahan, atau penerimaan sesorang dengan ancaman kekerasan, pengunaan kekerasan, penculikan, penyekapan, pemalsuan, penipuan, penyalahgunaan kekuasaan atau posisi rentan, penjeratan utang atau memberi bayaran atau manfaat, sehingga memperoleh persetujuan dari orang yang memgang kendali atas orang lain tersebut, baik yang dilakukan di dalam Negara maupun antarnegara, untuk tujuan mengeksploitasi atau mengakibatkan orang tereksploitasi.

Pasal 1 (ayat 2) menyatakan bahwa tindak pidana perdagangan orang adalah setiap tindakan atau serangkaian tindakan yang memenuhi unsurunsur tindak pidana yang ditentukan dalam undangundang ini, (substansi hukum bersifat formil karena berdasar pembuktian atas tujuan kejahatan trafiking, hakim dapat menghukum seseorang).

Perdagangan manusia mencakup serangkaian masalah kompleks dan isu-isu sensitif yang ditafsirkan secara berbeda oleh setiap orang, tergantung pada sudut pandang pribadi atau organisasi mereka. Meskipun demikian sebagaimana dinyatakan oleh dua ahli internasional, Wijers dan Lap-Chew bahwa "masalah definisi bukanlah masalah akademis. Langkah-langkah yang akan diambil untuk mencegah dan memberantas" perdagangan manusia dapat bervariasi tergantung pada bagaimana masalahnya didefinisikan. Di masa lalu perdagangan dipandang sebagai pemindahan paksa perempuan ke luar negeri untuk tujuan pelacuran. Tetapi kemudian perdagangan didefinisikan sebagai pergerakan orang (terutama perempuan dan anak-anak), dengan atau tanpa persetujuan dari orang yang bersangkutan di suatu negara atau di luar negeri, untuk semua bentuk tenaga kerja eksploitatif. 
Pola atau modus operandi yang di pergunakan dalam perdagangan orang diawali dengan tahapantahapan manipulatif, menjanjikan calon korban pekerjaan dengan gaji yang tinggi tanpa di beritahukan jenis dan resiko dari pekerjaan tersebut, jelas penawaran tersebut merupakan suatu peluang untuk meningkatkan taraf hidup dan perekonomian dari keluarga, setelah korban berhasil diyakinkan oleh para calo, maka para perempuan dan anakanak ditampung di suatu tempat yang jauh dari keramaian, kemudian korban-korban tersebut dipindahtangankan dari calo yang satu ke tangan calo yang lain dengan diikuti transaksi jual beli (Pudjiono, \& Nugroho, 2014).

Namun pada kenyataannya yang ada saat ini perdagangan orang masih banyak terjadi. Dalam catatan laporan tentang perdagangan orang di Indonesia pada tahun 2018, Indonesia merupakan salah satu negara asal utama dan pada tataran tertentu menjadi negara tujuan serta transit bagi lakilaki, perempuan, dan anak-anak Indonesia untuk menjadi pekerja paksa dan korban perdagangan seks. Seluruh provinsi (34 provinsi) di Indonesia merupakan daerah asal sekaligus tujuan perdagangan orang. Pemerintah memperkirakan sekitar 1,9 juta dari 4,5 juta warga Indonesia yang bekerja di luar negeri, kebanyakan dari mereka adalah perempuan tidak memiliki dokumen atau telah tinggal melewati batas izin tinggal. Situasi ini meningkatkan kerentanan mereka terhadap perdagangan orang. Jumlah sebenarnya jauh lebih besar mengingat banyaknya buruh migran yang secara turun temurun mengelak untuk memenuhi persyaratan penempatan dan izin bekerja ke luar negeri yang diterbitkan oleh pemerintah, yang kerap dilakukan atas hasutan pelaku perdagangan orang (Kedutaan Besar dan Konsulat AS di Indonesia, 2018).

Banyak warga Indonesia dieksploitasi menjadi pekerja paksa dan terlilit hutang di Asia dan Timur Tengah, terutama di sektor pekerja rumah tangga, buruh pabrik, pekerja konstruksi, pekerja manufaktur, perkebunan kelapa sawit di Malaysia, dan kapalkapal penangkap ikan yang beroperasi di Samudra Hindia dan Samudra Pasifik. Malaysia tetap menjadi tujuan utama bagi pekerja migran Indonesia; pemerintah memperkirakan lebih dari satu juta dari 1,9 juta pekerja Indonesia yang berstatus tidak resmi berada di Malaysia. Perempuan Indonesia dewasa dan remaja menjadi sasaran perdagangan seks, terutama di Malaysia, Taiwan, dan Timur Tengah. Pekerja rumah tangga merupakan mata pencaharian terbanyak yang dilakukan oleh perempuan Indonesia yang bekerja di Indonesia maupun di Singapura, Malaysia, Hong Kong dan Timur Tengah, namun mereka tidak dianggap sebagai pekerja formal dan tidak dilindungi oleh undang-undang ketenagakerjaan setempat. Jam kerja yang berlebihan, tidak adanya kontrak kerja resmi, dan gaji yang tidak dibayar adalah beberapa perlakuan tidak wajar yang paling umum dihadapi oleh asisten rumah tangga asal Indonesia.

Berdasarkan penelitian sebelumnya oleh, Perdana Eliakhim Manula, Suhaidi, Hamdan, Hasim 
Purba, yang berfokus pada Sanksi Pidana Terhadap Pelaku Tindak Pidana Perdagangan Orang (Studi Beberapa Putusan Pengadilan Negeri di Indonesia) (Manula, Suhaidi, Hamdan, Purba,. 2014).

Oleh Udiyo Basuki, yang berfokus pada Penegakan Hukum Atas Tindak Pidana Perdagangan Orang Perspektif Hak Asasi Manusia (Basuki, 2017).

Serta oleh Rr. Rina Antasari, yang berfokus pada Penanganan Tindak Pidana Perdagangan Orang dalam Perspektif Global dan Islam di Provinsi Sumatera Barat (Antasari, 2018).

Pada penelitian internasional oleh Brenda Carina Oude Breuil, Dina Siegel, Piet van Reenen, Annemarieke Beijer \& Linda Roos, dimana penelitian ini berfokus pada korban dan pelaku yang dibayangkan dalam narasi tentang perempuan diperdagangkan ke eropa untuk eksploitasi seksual (Breuil, Siegel, Reenen, Beijer, \& Roos, 2011).

Oleh David Nelken, yang berfokus pada pencegahan, menekan dan menghukum perdagangan orang (Nelken, 2010)

Berdasarkan penelitian sebelumnya diatas baik nasional dan internasional yang sama-sama bertemakan Perdagangan Orang, namun pada penelitian kali ini lebih berfokus pada Penerapan Sanksi Pidana Terhadap Pelaku Perdagangan Manusia (Human Trafficking) Di Indonesia.

\section{B. METODE PENELITIAN}

Metode penelitian ini menggunakan metode penelitian yuridis normatif dimana melihat permasalahan dari kajian bahan-bahan sebagai referensi yang digunakan adalah peraturan perundang-undangan sebagai bahan pokok (bahan hukum primair) dan bahan hukum sekunder adalah seperti literatur-literatur, buku-buku hukum, karya ilmiah, artikel-artikel ilmiah yang membahas tentang pengaturan dan penerapan sanksi pidana terhadap pelaku perdagangan orang (human trafficking).

\section{HASIL dan PEMBAHASAN}

\section{Pengaturan Hukum Terhadap Perdagangan} orang Human Trafficking di Indonesia

\section{a. Perdagangan orang menurut Kitab Undang- Undang Hukum Pidana}

Perdagangan orang merupakan bentuk perlakuan yang buruk dari pelanggaran harkat dan martabat manusia. Perdagangan orang ini telah meluas dalam bentuk jaringan kejahatan yang terorganisasi baik bersifat antar negara maupun luar negeri (Suhardin, 2008). Kejahatan yang terorganisir ini juga membuat pemerintah kerepotan dalam penanggulangannya maunpun dalam memberikan perlindungan kepada korban (Alfian, 2015). Bloomsburry menyebut Perdagangan orang (Human Trafficking) dengan istilah Trafficking in Person yang diartikan sebagai "The illegal practice of finding and using human beings for unpaid often unpleasant work in situations their circumtances prevent them from living (Fadilla, 2016).

Maraknya perdagangan orang di berbagai negara, termasuk Indonesia dan negara-negara yang sedang berkembang telah menjadi perhatian dunia 
dan terutama Perserikatan Bangsa-Bangsa (PBB) (Widiastuti, 2010).

Kegiatan perdagangan orang sedari awal dilarang, baik di Amerika Serikat maupun di Indonesia. Perbuatan perdagangan orang telah dikategorikan sebagai tindak pidana lebih tepatnya lagi tindak pidana khusus. Dalam sistem hukum pidana Indonesia, tindak pidana khusus diatur dan bersumber dari kaedah hukum pidana yang ada di luar KUHP (Effendi, 2013).

Ketentuan mengenai larangan perdagangan orang pada dasarnya telah diatur didalam Kitab Undang-Undang Hukum Pidana (KUHP).

Pasal 297 KUHP:

"Barang siapa dengan sengaja menyebabkan atau memudahkan perdagangan anak laki-laki yang belum dewasa, diancam dengan pidana penjara paling lama enam tahun".

Pasal 298 KUHP berbunyi :

Ayat 1 : Dalam hal pemidanaan berdasarkan salah satu kejahatan dalam pasal 281, 284, 290 dan 297 pencabutan hak-hak berdasarkan Pasal 35 No 1-5 dapat dinyatakan.

Ayat 2 : Jika yang bersalah melakukan salah satu kejahatan berdasarkan pasal 261, 297 dalam melakukan pencahariannya, maka hak untuk melakukan pencaharian itu dapat dicabut.

Pasal 83 Undang-Undang Nomor 23 Tahun 2002 tentang Perlindungan Anak Menentukan larangan memperdagangkan anak, menjual atau menculik anak itu sendiri atau dijual (Hanim, \& Prakoso, 2015). Ketentuan dalam KUHP memberikan sanksi hukum yang terlalu ringan dan tidak seimbang dengan dampak yang ditimbulkan akibat kejahatan perdagangan orang, oleh karenanya diperlukan undang-undang khusus tentang tidank pidana perdagangan orang yang mampu meyediakan landasan hukum materil dan formil sekaligus. Guna tujuan tersebut maka undang-undang khusus ini mengantisipasi dan menjerat semua bentuk eksploitasi yang mungkin terjadi dalam praktik perdagangan orang baik yang dilakukan antar wilayah dalam negeri maupun antar Negara dan oleh pelaku perorangan maupun korporasi, untuk melaksanakan protocol PBB tahun 2006 tentang Pencegahan, Pemberantasan dan Penghukuman terhadap Tidak Pidana Perdagangan Orang khususnya perempuan dan anak-anak yang telah ditanda tangani pemerintah Indonesia (Damanik, \& Siregar, 2014).

Pada perkembangan pengaturan undangundang perdagangan orang di Indonesia UU No. 21 Tahun 2007 tentang pemberantasan tindak pidana perdagangan orang disahkan, digunakan KUHP Pasal 297 yang berbunyi "perdagangan perempuan dan anak laki-laki yang belum dewasa, diancam dengan pidana penjara paling lama 6 tahun, dan hanyalah pasal ini yang secara khusus menyebutkan perdagangan orang, walaupun demikian hal ini masih sangatlah tidak lengkap dan belum mengakomodasi perlindungan hukum terhadap perdaganan orang.

Secara makna pasal-pasal tentang perbudakan dibutuhkan lagi, dalam RUU KUHP dimunculkan kembali di mana perbuatan pidana yang 
disebut dengan perbudakan itu disesuaikan dengan keadaan sekarang dengan perbuatan pidana perdagangan orang, yang terdapat dalarn Bab XX Tindak pidana Kemerdekaan orang, Pasal 526 sampai dengan pasal 541 tentang perdagangan Orang.

Menurut Undang-Undang Nomor 26 Tahun 2000 tentang Pengadilan Hak Asasi Manusia bahwa perdagangan orang merupakan salah satu pelanggaran Hak Aasasi Manusia termasuk kejahatan terhadap kernanusiaan. Dalam Pasal 9 menyebutkan kejahatan kemanusiaan adalah salah satu perbuatan yang dilakukan sebagai bagian dari serangan yang meluas atau sistematis yang diketahuinya bahwa serangan tersebut ditujukan secara langsung terhadap penduduk sipil. Selain itu, Indonesia telah menandatangani UN Convention Trannational Organized Crimes berserta protokoinya yaitu Protokol to Prevenf, Suppress and Punish Trafficking in Persons, Especially Women and Children, dan Protokol Againstthe Smuggling of Migrants by Land, Sea and Air, pada Desember 2000 di Palermo Itali, yang tentunya dalam rangka menyikapi adanya implikasi- implikasi hukum atas tindakan perdagangan orang. Oleh karena itu, pemerintah Indonesia bulan April 2007 telah mensahkan undang-undang tindak pidana perdagangan orang (Hidayati, 2012).

Berdasarkan Undang-undang No. 21 Tahun 2007 tentang Pemberantasan Tindak Pidana Perdagangan Orang, bentuk kejahatan eksploitasi seksual komersial anak berupa perdagangan (trafficking) anak untuk tujuan seksual diatur dalam pasal 2 yaitu:

Pasal 2: (1) Setiap orang yang melakukan perekrutan, pengangkutan, penampungan, pengiriman, pemindahan, atau penerimaan seseorang dengan ancaman kekerasan, penggunaan kekerasan, penculikan, penyekapan, pemalsuan, penipuan, penyalahgunaan kekuasaan atau posisi rentan, penjeratan utang atau memberi bayaran atau manfaat walaupun memperoleh persetujuan dari orang yang memegang kendali atas orang lain, untuk tujuan mengeksploitasi orang tersebut di wilayah negara Republik Indonesia, dipidana dengan pidana penjara paling singkat 3 (tiga) tahun dan paling lama 15 (lima belas) tahun dan pidana denda paling sedikit Rp120.000.000,00 (seratus dua puluh juta rupiah) dan paling banyak Rp600.000.000,00 (enam ratus juta rupiah). (2) Jika perbuatan sebagaimana dimaksud pada ayat (1) mengakibatkan orang tereksploitasi, maka pelaku dipidana dengan pidana yang sama sebagaimana dimaksud pada ayat (1).

Pasal 2 angka 1 Undang-Undang No. 21 Tahun 2007 tentang Pemberantasan Tindak Pidana Perdagangan Orang, terdapat kata "untuk tujuan" sebelum frasa mengeksploitasi orang menunjukkan bahwa tindak pidana perdagangan orang merupakan delik formil, yaitu adanya tindak pidana perdagangan orang cukup dengan dipenuhinya unsur-unsur perbuatan yang sudah dirumuskan, dan tidak harus menimbulkan akibat. Selain Pasal 2 Undang-undang No. 21 Tahun 2007 tentang Pemberantasan Tindak Pidana Perdagangan Orang terdapat ketentuan 
pidana lain di Undang-undang tersebut yaitu Pada Pasal 3, Pasal 4, Pasal 5 dan Pasal 6 Undangundang No. 21 Tahun 2007. Di dalam Undangundang No. 21 Tahun 2007, terdapat penambahan ancaman pidana sebanyak 1/3 (sepertiga) apabila korban menderita luka berat, gangguan jiwa berat, penyakit menular lainnya yang membahayakan jiwanya, kehamilan, atau terganggu atau hilangnya fungsi reproduksinya. Hal tersebut sesuai dengan Pasal 7 yang berbunyi:

Pasal 7: (1) Jika tindak pidana sebagaimana dimaksud dalam Pasal 2 ayat (2), Pasal 3, Pasal 4, Pasal 5, dan Pasal 6 mengakibatkan korban menderita luka berat, gangguan jiwa berat, penyakit menular lainnya yang membahayakan jiwanya, kehamilan, atau terganggu atau hilangnya fungsi reproduksinya, maka ancaman pidananya ditambah 1/3 (sepertiga) dari ancaman pidana dalam Pasal 2 ayat (2), Pasal 3, Pasal 4, Pasal 5, dan Pasal 6. (2) Jika tindak pidana sebagaimana dimaksud dalam Pasal 2 ayat (2), Pasal 3, Pasal 4, Pasal 5, dan Pasal 6 mengakibatkan matinya korban, dipidana dengan pidana penjara paling singkat 5 (lima) tahun dan paling lama penjara seumur hidup dan pidana denda paling sedikit Rp200.000.000,00 (dua ratus juta rupiah) dan paling banyak Rp5.000.000.000,00 (lima milyar rupiah).

2. Penerapan Sanksi Pidana terhadap Pelaku Perdagangan Manusia (Human Trafficking) Hukum pidana menentukan sanksi terhadap setiap pelanggaran hukum yang dilakukan. Sanksi itu pada prinsipnya merupakan penambahan penderitaan dengan sengaja. Penambahan penderitaan dengan sengaja ini pula yang menjadi pembeda terpenting antara hukum pidana dengan hukum yang lainnya (Bemmelen, 1987).

Pada dasarnya kepada seorang pelaku suatu tindak pidana harus dikenakan suatu akibat hukum. Akibat hukum itu pada umumnya berupa hukuman pidana atau sanksi. Berdasarkan Pasal 10 KUHP jenis hukuman pidana dibagi menjadi dua, yaitu: (Bemmelen, 1987)

a. Pidana pokok yang terdiri dari pidana mati, pidana penjara, pidana kurungan, pidana denda, pidana tutupan;

b. Pidana tambahan terdiri dari pencabutan hak-hak tertentu, perampasan barang-barang tertentu, dan pengumuman putusan hakim.

Satochid Kartanegara berpendapat bahwa "hukuman (pidana) adalah penyiksaan atau penderitaan, yang oleh hukum pidana diberikan kepada seseorang yang melanggar norma yang ditentukan oleh hukum pidana, dan bahwa penyiksaan atau penderitaan oleh keputusan hakim dijatuhkan pada orang yang dipersalahkan karena itu. Sifat dalam bentuk siksaan atau penderitaan harus diberikan pada hukuman (pidana), karena pelanggaran yang dilakukan seseorang terhadap norma yang ditentukan oleh hukum pidana adalah pelanggaran atau perkosaan kepentingan hukum yang akan dilindungi oleh hukum pidana" (Kartanegara, 1954-1955). 
Menurut Herbert L. Packer, sanksi pidana adalah suatu alat atau sarana terbaik yang tersedia, yang dimiliki untuk menghadapi kejahatan-kejahatan atau bahaya besar serta untuk menghadapi ancaman-ancaman. Selanjutnya Packer menyatakan bahwa :

a. Sanksi pidana sangatlah diperlukan; kita tidak dapat hidup, sekarang maupun dimasa yang akan datang, tanpa pidana.

b. Sanksi pidana merupakan alat atau sarana terbaik yang tersedia, yang kita miliki utk menghadapi kejahatan-kejahatan atau bahaya besar dan segera serta utk menghadapi ancaman-ancaman dari bahaya.

c. Sanksi pidana suatu ketika merupakan penjamin yang utama dari kebebasan manusia. la merupakan penjamin apabila digunakan secara hemat-cermat dan secara manusiawi, ia merupakan pengancam apabila digunakan secara sembarangan dan secara paksa (Packer, 1967).

Penerapan sanksi pidana di Indonesia yang implementasinya pada dalam Kitab Undang-Undang Hukum Pidana (KUHP), penjatuhan sanksi pidana terhadap tindak pidana perdagangan orang (human trafficking) dalam KUHP diatur didalam buku II Pasal 295 ayat (1) angka 1 dan 2, Pasal 295 ayat (2), Pasal 296, Pasal 297, Pasal 298 ayat (1),(2) dan Pasal 506. Dari pengertian yang terdapat di dalam KUHP dapat dijabarkan sebagai berikut: (Maharani, \& Atmadja, 2015)

- Dengan sengaja menyebabkan atau memudahkan perbuatan cabul yang korbannya anak (kandung, tiri,angkat) dan anak-anak dibawah pengawasannya; perbuatan pelaku sebagai mata pencaharian;

- Perbuatan yang sama, tapi untuk orang dewasa;

- Memperniagakan perempuan dan anak laki-laki;

- Ada hukuman tambahan (1) pencabutan hak (asuh untuk prlaku yang korbannya anak), (2) pemecatan dari pekerjaan kalau kejahatan dilakukan dalam pekerjaannya

Undang-Undang nomor 21 tahun 2007 tentang pemberantasan tindak pidana perdagangan orang ini memberikan sanksi pidana yang cukup berat terhadap pelaku tindak pidana perdagangan manusia sebagai wujud perlindungan terhadap korban perdagangan manusia. Ketentuan pidana terdapat dalam pasal 2 hingga pasal 23 UndangUndang nomor 21 tahun 2007 tentang pemberantasan tindak pidana perdagangan orang. Salah satu contoh Pasal 2 yang mengatur tentang dapat dipidananya perbuatan seorang pelaku perdagangan manusia baik secara melawan hukum maupun memperoleh persetujuan dari orang yang memegang kendali atas orang lain yang bertujuan untuk mengeksploitasi. Pasal 2 Undang-Undang nomor 21 tahun 2007 tentang pemberantasan tindak pidana perdagangan tersebut berbunyi :

"Setiap orang yang melakukan perekrutan, pengangkutan, penampungan, pengiriman, pemindahan, atau penerimaan seseorang dengan ancaman kekerasan, penggunaan kekerasan, penculikan, penyekapan, pemalsuan, penipuan, penyalahgunaan kekuasaan atau posisi rentan, 
penjeratan utang atau memberi bayaran atau manfaat walaupun memperoleh persetujuan dari orang yang memegang kendali atas orang lain, untuk tujuan mengeksploitasi orang tersebut di wilayah negara Republik Indonesia, dipidana dengan pidana penjara paling singkat 3 (tiga) tahun dan paling lama 15 (lima belas) tahun dan pidana denda paling sedikit Rp120.000.000,00 (seratus dua puluh juta rupiah) dan paling banyak Rp. $600.000 .000,00$ (enam ratus juta rupiah).

Dalam rumusan Pasal 1 angka 4 UU No 21 Tahun 2007, pelaku adalah setiap orang perseorangan atau korporasi yang melakukan tindak pidana perdagangan manusia. Dalam pasal 2 sampai dengan 18, undang-undang ini secara tegas merumuskan sanksi terhadap pelaku perdagangan orang. Berdasarkan pasal-pasal tersebut, dapat dikategorikan beberapa pelaku Tindak Pidana Perdagangan Orang, yaitu: Pertama, Agen perekrutan Tenaga Kerja (legal atau illegal) yang membayar agen/ calo untuk mencari buruh di desadesa, mengelola penampungan, mengurus identitas serta KTP dan dokumen perjalanan, memberikan pelatihan dan pemeriksaan medis serta menempatkan buruh dalam kerjaannya di Negara tujuan. Meskipun tidaksemua, namun sebagian PJTK terdaftar melakukan tindakan demikian. Kedua, Agen/calo (mungkin orang asing) yang datang ke suatu desa, tetangga, teman, bahkan kepala desa, tokoh masyarakat, tokoh adat, maupun tokoh agama. Agen dapat bekerja secara bersamaan untuk PJTK terdaftar /tidak terdaftar, guna memperoleh bayaran untuk tiap buruh yang direkrutnya. Ketiga, Majikan yang memaksa buruh bekerja dalam kondisi eksploitatif, tidak membayar gaji, menyekap buruh di tempat kerja, melakukan kekerasan seksual atau fisik terhadap buruh. Keempat, Pemerintah, yang terlibat dalam pemalsuan dokumen, mengabaikan pelanggaran dalam perekrutan tenaga kerja atau memfasilitasi penyeberangan perbatasan secara illegal (termasuk pembiaran oleh polisi/petugas imigrasi). Kelima, Pemilik/pengelola rumah bordil yang memaksa perempuan untuk bekerjadi luar kemauan dan kemampuannya, tidak membayar gaji atau merekrut dan mempekerjakan anak yang belum berusia 18 tahun.

\section{SIMPULAN}

Dari uraian diatas dapat diambil kesimpulan, bahwa tindak pidana perdagangan orang merupakan kejahatan yang terorganisir secara sistematis, dimana orang-orang yang termasuk didalamnya memiliki kepentingan-kepentingan secara pribadi dan atau kelompok. Tindak pidana perdagangan orang ini juga dikategorikan sebagai kejahatan yang melanggar HAM seseorang, dimana para pelaku menjajakan orang-orang untuk menjadi pekerjapekerja yang memberikan keuntungan bagi mereka.

Oleh karena itu, kajian yang diangkat ini merupakan langkah yang diharapkan bisa menjadi salah satu cara untuk memberantas tindak pidana perdagangan orang. 


\section{DAFTAR PUSTAKA}

\section{BUKU}

Bemmelen, V. (1987). Hukum Pidana 1 Hukum Pidana Material Bagian Umum. Bandung : Binacipta.

Kartanegara, S. (1954-1955). Kumpulan Catatan

Kuliah Hukum Pidana II. Bandung : Binacipta.

Koeswadji. (1995). Perkembangan Macam-macam

Pidana Dalam Rangka Pembangunan Hukum

Pidana. Bandung: Citra Aditya Bhakti.

Packer, Herbert L. (1967). The Limits of The

Criminal Sanction. California: Stanford

California University Press.

\section{JURNAL}

Alfian, A. (2015). Upaya Perlindungan Hukum Terhadap Korban Tindak Pidana Perdagangan Orang. Fiat J ustisia J urnal IImu Hukum, Vol.9, (No. 3, Juli-September), pp-331-339.

Antasari, Rr Rina. (2018). Penanganan Tindak

Pidana Perdagangan Orang dalam Perspektif Global dan Islam di Provinsi Sumatera Barat. Intizar, Vol.24, (No.1), pp.115-140.

Azizurrahman, Syarif H. (2014). Pembaharuan Kebijakan Pidana Kejahatan Perdagangan Orang (Studi di Wilayah Perbatasan Kalimantan Barat-Sarawak). Yustisia, Vol. 3, (No. 2 Mei-Agustus), pp-88-99.

Basuki, U. (2018). Penegakan Hukum Atas Tindak Pidana Perdagangan Orang Perspektif Hak Asasi Manusia. Varia J usticia, Vol.13, (No.2 Oktober), pp-132-146.
Breuil, Brenda Carina Oude., Siegel, Dina., Reenen, Piet van., Beijer, Annemarieke., \& Roos, Linda. (2011). Human trafficking revisited: legal, enforcement and ethnographic narratives on sex trafficking to Western Europe. Trends in Organized Crime, Vol.14, (Issue 1, maret), pp30-46.

Damanik, Jalison., \& Siregar, Taufik. (2014). Penerapan Sanksi Hukum Terhadap Pelaku Kejahatan Trafficking (Studi Putusan di Pengadilan Negeri Binjai). J urnal Medika, Vol. 7, (No. 2/ Desember), pp-109-124.

Effendi, E. (2013). Pemberantasan Perdagangan Orang Dengan Sarana Hukum Pidana. J urnal Cita Hukum, Vol. I, (No. 1 Juni), pp-85-98.

Fadilla, N. (2016). Upaya Perlindungan Hukum Terhadap Anak Sebagai Korban Tindak Pidana Perdagangan Orang. Jurnal Hukum dan Peradilan, Vol.5, (Nomor 2, Juli), pp-181194.

Hanim, Lathifah., \& Prakoso Putro, Adityo. Perlindungan Hukum Terhadap Korban Kejahatan Perdagangan Orang (Studi Tentang Implementasi UU No. 21 Tahun 2007). J urnal Pembaharuan Hukum, Volume II No. 2 MeiAgustus, pp-234-244.

Hidayati, Maslihati N. (2012). Upaya Pemberantasan Dan pencegahan Perdagangan Orang Melalui Hukum Internasional dan Hukum Positif Indonesia. Jurnal Al-Azhar Indonesia Seri Pranata Sosial, Vol. 1, (No. 3, Maret), pp-163175. 
Kamea, Herlien C. (2016). Penegakan Hukum Pidana Terhadap Kejahatan Perdagangan Orang Menurut Undang-Undang Nomor 21 Tahun 2007. Lex Criemen, Vol.V, (No.2/Feb), pp-126-133.

Maharani, I. Gst. Ayu Stefani Ratna., \& Atmadja, Ida Bagus Putra. (2015). Sanksi Pidana Terhadap Tindak Pidana Perdagangan Orang (Human Trafficking) di Indonesia. Kertha Wicara, Vol. 04, (No. 03, September), pp-1-5.

Manula, Perdana Eliakhim., Suhaidi., Hamdan., \& Purba, Hasim. (2014). Sanksi Pidana Terhadap Pelaku Tindak Pidana Perdagangan Orang (Studi Beberapa Putusan Pengadilan Negeri di Indonesia). USU Law J urnal, Vol.2, (No.3 Desember), pp-176-189.

Munthe, R. (2015). Perdagangan Orang (Trafficking) Sebagai Pelanggaran Hak Asasi Manusia. J upiis, Vol 7, (No.2), pp-184-192.

Nelken, D. (2010). Human Trafficking And Legal Culture. Israel Law Review, Vol.43, (Issue 3), pp-479-513.

Pudjiono, Moch Juli., \& Nugroho, Sigit Sapto. (2014).

Pertanggung Jawaban Pidana Pelaku Tindak Pidana Perdagangan Orang (Trafficking). J urnal Sosial, Vol.15, (No.1, Maret), pp-43-53.

Prakoso, Abdul Rahman., \& Nurmalinda, Putri Ayu. (2018). Kebijakan Hukum Terhadap Tindak Pidana Perdagangan Orang. Seminar Nasional Hukum Universitas Negeri Semarang, Vol.4, (No.1), pp-1-24.
Rahmawati, R. (2016). Penyimpangan Sosial Human Trafficking. J urnal Equelibrium, Vol.IV, (No. 1 Mei), pp-30-37.

Riadi, W. (2017). Implementasi Pencegahan Perdagangan Orang Dari Perspektif Pertahanan Negara. Jurnal Strategi Perang Semesta, Vol.3, (No.2, Juni), pp-1-24.

Rosnawati., Din, Mohd., \& Mujibussalim. (2016). Kepastian Hukum Hak Restitusi Terhadap Korban Tindak Pidana Perdagangan Orang (TPPO) Berdasarkan Undang-Undang Nomor 21 Tahun 2007. Jurnal IImu Hukum, Vol 4, (No, 1, Februari), pp-1-7.

Satriani, Ari, Rizka., \& Muis, Tamsil. (2013). Studi Tentang Perdagangan Manusia (Human Trafficking) Pada Remaja Putri Jenjang Sekolah Menengah Di Kota Surabaya. Jurnal BK Unesa, Vol.4, (No.1), pp-67-78.

Suhardin, Y. (2008). Tinjauan Yuridis Mengenai Perdagangan Orang Dari Perspektif Hak Asasi Manusia. Mimbar Hukum, Vol.20, (No.3, Oktober), pp-411-588.

Widiastuti, Tri W. (2010). Upaya Pencegahan Tindak Pidana Perdagangan Orang. Wacana Hukum, Vol. 9, (No. 1, April), pp-107-120.

\section{PERUNDANG-UNDANGAN}

Kitab Undang - undang Hukum Acara Pidana, Undang - undang Nomor 8 Tahun 1981.

Kitap Undang-Undang Hukum Pidana. Undang - Undang Dasar Negara Republik Indonesia Tahun 1945. 
Jurnal Pembangunan Hukum Indonesia

Volume 1, Nomor 3, Tahun 2019

Undang - Undang No. 21 Tahun 2007 tentang Pemberantasan Tindak Pidana Perdagangan Orang.

\section{SUMBER ONLINE}

Kedutaan Besar dan Konsulat AS di Indonesia. (2018). Laporan Tahunan Perdagangan Orang 2018, Retrieved from https://id.usembassy.gov/id/our-relationshipid/official-reports-id/laporan-tahunanperdagangan-orang-2018/, diakses pada 02 Sep. 19
Program Studi Magister Ilmu Hukum Fakultas Hukum Universitas Diponegoro 